\title{
Treatment of Landfill Leachate Using Ganoderma Australe Mycelia Immobilized on Ecomat
}

\author{
Noorlidah Abdullah, Wan Razarinah W. A. R., Noor Zalina Mahmood, and Rosna Mat Taha
}

\begin{abstract}
Biological processes have been proven to be efficient in treating landfill leachates. In this study, treatment of landfill leachate by Ecomat-immobilized mycelia of Ganoderma australe packed in a column was investigated. Continuous recycling of leachate at a constant flow $(20 \mathrm{ml} / \mathrm{min})$ was operated for 10 cycles to facilitate biological reactions. Diluted leachate $(50 \%)$ and raw leachate $(100 \%)$ were tested for comparison of efficiency of treatment. The results showed that biological oxygen demand $\left(\mathrm{BOD}_{5}\right)$ was not removed for diluted leachate and a slight removal of 0.14 and $1.72 \%$ for raw leachate after cycles 4 and 10, respectively. Chemical oxygen demand (COD) removal occurred after each cycle with diluted leachate demonstrating higher removal compared to raw leachate. The highest percentage of COD removal of $51.62 \%$ for diluted leachate and $\mathbf{2 2 . 7 9 \%}$ for raw leachate were achieved after the tenth cycle. Ecomat-immobilized mycelium of Ganoderma australe could also reduce ammoniacal nitrogen $\left(\mathrm{NH}_{3}-\mathrm{N}\right)$ exhibiting highest reduction of $45.95 \%$ and $30.90 \%$ after cycle 8 for diluted and raw leachate, respectively. These findings suggested that a white rot fungus, $G$. australe has the ability to be considered as potential candidate in landfill leachate treatment.
\end{abstract}

Index Terms-Fungal enzymes, ammoniacal nitrogen, chemical oxygen demand, biological treatment, white-rot fungi.

\section{INTRODUCTION}

Sanitary landfill leachate is a highly polluted and complex wastewater. Its quality is the result of biological, chemical and physical processes in landfills combined with the specific waste composition and the landfill water regime [1]. Biological treatment is the most common practice for leachate treatment worldwide but the remaining values of COD and adsorbable organic halogenated compounds (AOX) are still relatively high [2]. With increasing leachate effluent quality standards the efforts for leachate treatment also increase.

White-rot basidiomycetous fungi have been implicated in the transformation of a large amount of organopollutants structurally related to lignin [3], [4]. Besides that, the use of

Manuscript received March 4, 2013; revised May 8, 2013. This work was funded by University of Malaya grant no. IPPP PS148/2009A and Ministry of Higher Education for the Exploratory Reseacrh Grant Scheme ERGS019-2011A.

Noorlidah Abdullah and Noor Zalina Mahamood are with the Mushroom Research Centre (MRC), Institute of Biological Sciences, Faculty of Science, University of Malaya, 50603 Kuala Lumpur, Malaysia (e-mail: noorlidah@um.edu.my, email: alin@um.edu.my).

Wan Razarinah W. A. R. is with University of Technology MARA, Faculty of Applied Sciences, 40450 Shah Alam, Selangor, Malaysia (email: razarina408@salam.uitm.edu.my).

Rosna Mat Taha is with Institute of Biological Sciences, Faculty of Science, University of Malaya, 50603 Kuala Lumpur, Malaysia (email: rosna@um.edu.my). fungal cultures to transform various chemical compounds has already been reported in several studies [5]. White rot fungi are capable of producing extracellular lignin peroxidase (LiP) and manganese-dependent peroxidase $(\mathrm{MnP})$ that is essential for lignin degradation. Gold, and Alic, [6] demonstrated white rot fungi such as Phanerochaete chrysosporium typically secrete one or more of the three principal ligninolytic enzymes, i.e. lignin peroxidase (LiP, E.C. 1.11.1.14), Mn-dependent peroxidase (MnP, E.C. 1.11.1.13) and phenol oxidase (Laccase) (Lac, E.C. 1.10.3.2). These enzymes are able to oxidize a variety of high-priority aromatic pollutants, such as polycyclic aromatic hydrocarbons [7], chloromatics and polyaromatic dyes [8]. Therefore, white rot fungi are of current interest to be used in the bioremediation of a broad spectrum of persistent xenobiotic and to treat wastewater, including landfill leachate.

Mohammadi and Nasernejad, [9] had reported the limitation of using $P$. chrysosporium free cells in the biodegradation process therefore, cell immobilization offers a suitable alternative. Immobilized cultures tend to have higher level of enzymes activity and were more resilient to environmental perturbations such as $\mathrm{pH}$ or exposure to toxic chemicals compared to free cell culture. According to Ramakrishna and Prakasham, [10], immobilization of cells is the attachment of cells or their inclusion in distinct solid phase that permits exchange of substrates, products, inhibitors, etc., but at the same time separates the catalytic cell biomass from the bulk phase containing substrates and products. Mycelial immobilization has been used for the production of ligninolytic enzymes and bioremediation of pollutants. To our knowledge, G. australe has not been investigated for it's potential use in bioremediation. Thus, the objective of this study is to investigate the ability of mycelium of a white-rot fungus, Ganoderma australe immobilized on Ecomat and packed in a column to remediate leachate.

\section{MATERIALS AND METHODS}

\section{A. Fungal Culture}

Ganoderma australe was maintained on malt extract agar (MEA) slants, and mycelial culture was prepared by growing on MEA in Petri plates for 7 days at $28 \pm 2^{\circ} \mathrm{C}$.

\section{B. Productivity of Extracellular Enzymes by G. Australe}

Seven days old mycelium of G. australe was inoculated into 250-ml flasks containing sterile glucose-yeast-malt-peptone (GYMP) liquid medium added with $0.1 \%$ of skim milk, olive oil, veratryl alcohol, $\mathrm{MnCl}_{2}$, 
$\mathrm{CuSO}_{4}$ and starch. The GYMP growth medium contained the following: $\mathrm{MgSO}_{4} .7 \mathrm{H}_{2} \mathrm{O}(1.0 \mathrm{~g} / \mathrm{L}) ; \mathrm{KH}_{2} \mathrm{PO}_{4}(1.0 \mathrm{~g} / \mathrm{L})$; $\mathrm{K}_{2} \mathrm{HPO}_{4}(1.0 \mathrm{~g} / \mathrm{L}) ; \mathrm{NH}_{4} \mathrm{Cl}(1.0 \mathrm{~g} / \mathrm{L})$; Glucose $(15.0 \mathrm{~g} / \mathrm{L})$; Peptone $(8.0 \mathrm{~g} / \mathrm{L})$; Yeast extract $(8.0 \mathrm{~g} / \mathrm{L})$; and Malt extract $(8.0 \mathrm{~g} / \mathrm{L})$. Inoculated medium was incubated at $28 \pm 2{ }^{\circ} \mathrm{C}$ shaking at $150 \mathrm{rpm}$ for four days. Then, extracellular enzymes were extracted with $50 \mathrm{mM}$ sodium-phosphate buffer at $\mathrm{pH} 6.5$ for one hour shaking at $150 \mathrm{rpm}$. The mixture was then filtered through $1.5 \mu \mathrm{m}$ Whatman Millipore filter and the supernatant was analysed for enzyme activity.

\section{Enzymes Assays}

Lignin peroxidase (LiP) activity was determined by monitoring the conversion of veratryl alcohol to veratryl aldehyde at $25{ }^{\circ} \mathrm{C}$ by hydrogen peroxide $\left(\mathrm{H}_{2} \mathrm{O}_{2}\right)$ [11] Manganese peroxidase (MnP) activity was measured using guaicol as a subtrate. Laccase activity was determined by the increase in the absorbance at $\lambda=525$. This was due to the production of tetramethoxy-azo-bis-methylenequinone resulting from the reaction of laccase with syringaldazine [12], [13]. Protease activity was determined by mixing $0.5 \mathrm{ml}$ of enzyme with $0.5 \mathrm{ml}$ of $0.5 \%$ azocasein as the substrate. Lipase activity was determined with p-nitrophenyl palmitate by the method reported by Savitha et al. [14]. Amylase activity was determined using $1 \%$ soluble starch in citrate-phosphate buffer (pH 6.5) as substrate [15].

\section{Preparation of Mycelium Suspension and Immobilization of Mycelium on Ecomat}

Four mycelial plugs of $6-\mathrm{mm}^{2}$ diameter cut from the periphery of a 7-day old colony growing on MEA were transferred into 250-ml Erlenmeyer culture flasks containing $100 \mathrm{mls}$ of sterile GYMP. The $\mathrm{pH}$ of the media was adjusted to 6 before autoclaving. Inoculated flasks were then agitated on an orbital shaker at $150 \mathrm{rpm}$ for $48 \mathrm{~h}$ at $28 \pm 2{ }^{\circ} \mathrm{C}$ to obtain mycelial suspension.

Immobilization was done on Ecomat, a high-tech organic fibres made from $100 \%$ oil palm empty fruit bunches (manufactured by Ecofibre Technology, Malaysia) autoclaved for $1 \mathrm{hr}$. Four pieces of Ecomat of $1 \mathrm{~mm}$ thickness was cut into $2 \times 2 \mathrm{~cm}$ squares and added into $250-\mathrm{ml}$ Erlenmeyer culture flasks containing $50 \mathrm{mls}$ of GYMP medium and autoclaved. Then when cooled, $5 \mathrm{mls}$ of mycelium suspension was transferred aseptically and the flasks were agitated at $100 \mathrm{rpm}$ on an orbital shaker. The Ecomat was covered with fungal mycelium after 4 days of incubation and was used for leachate treatment.

\section{E. Leachate Sample}

Leachate sample used in this experiment was collected from the leachate pond at the sanitary landfill. The leachate was filtered to remove suspended solids and was analyzed for $\mathrm{pH}, \mathrm{COD}, \mathrm{BOD}_{5}$, and $\mathrm{NH}_{3}-\mathrm{N}$ according to the Standard Method for the Examination of Water and Wastewater [16] using Hach DR 2800 spectrophotometer.

\section{F. Treatment of Leachate Using Ecomat-Immobilized G. Australe Mycelia Packed in Column}

The experiment used diluted (50\%) and raw leachate (100\%) passed through a glass column packed with Ecomat-immobilized mycelium separately. Column used was
$40 \mathrm{~mm}$ diameter and $500 \mathrm{~mm}$ height. A total of 30 pieces of Ecomat-immobilized mycelia were arranged and packed. Treated leachate was compared to leachate passed through column packed with sterile Ecomat without fungal mycelium (control).

During treatment, 1 litre of leachate was passed through the column at the flow rate adjusted to $20 \mathrm{ml}$ per minute operated at room temperature. Treatment of leachate was conducted for ten cycles and after two cycles the leachate was analysed for $\mathrm{pH}, \mathrm{BOD}_{5}, \mathrm{COD}$ and $\mathrm{NH}_{3}-\mathrm{N}$. The experimental set-up of Ecomat-immobilized G. australe in column packing is shown in Fig. 1.

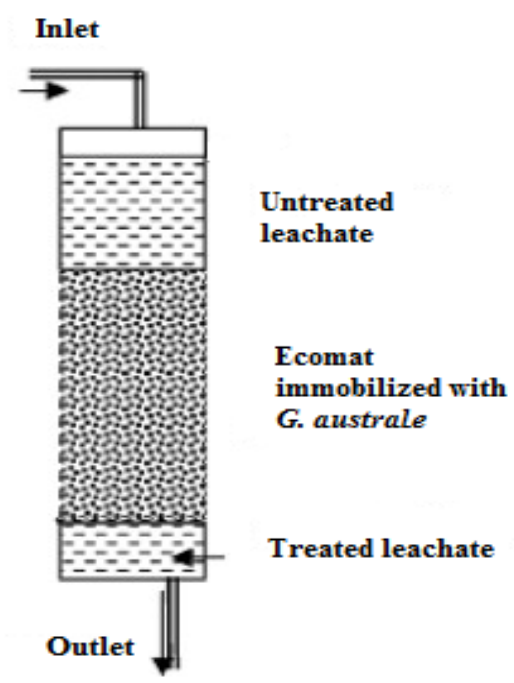

Fig. 1. Experimental set-up of Ecomat-immobilized G. australe packed in a glass column for the treatment of leachate.

\section{G. Leachate Analysis}

The degradation of leachate was determined by measuring the percentage removal of leachate contaminants denoted as $\mathrm{BOD}, \mathrm{COD}, \mathrm{NH}_{3} \mathrm{~N}$ and changes of $\mathrm{pH}$. These contaminants were analysed in accordance with the Standard Method for the Examination of Water and Wastewater [16] using Hach DR 2800 spectrophotometer.

\section{RESUlTS}

Extracellular enzymes produced by four-days old $G$. australe mycelium are shown in Table I. Results revealed that $G$. australe produced ligninolytic enzymes with the highest production of $\mathrm{MnP}(45.83 \pm 1.81 \mathrm{U} / \mathrm{ml})$ followed by laccase $(21.93 \pm 0.79 \mathrm{U} / \mathrm{ml})$ that are the important enzymes for pollutant degradation. A significant productivity of protease $(4.23 \pm 0.42 \mathrm{U} / \mathrm{ml})$ and $\mathrm{LiP}(1.30 \pm 0.60 \mathrm{U} / \mathrm{ml})$ were also observed. In addition, $G$. australe also exhibited low titers of lipase $(0.47 \pm 0.24 \mathrm{U} / \mathrm{ml})$ and amylase $(0.39 \pm 0.02$ $\mathrm{U} / \mathrm{ml})$.

TABLE I: PRODUCTIVITY OF LIGNIN PEROXIDASE, MANGANESE Peroxidase, Laccase, Protease, Lipase, AND Amylase by Four Days

\begin{tabular}{lr}
\multicolumn{2}{c}{ OLD MYCELIUM OF G. AUSTRALE } \\
\hline Enzymes & Enzyme activity (U/ml) \\
\hline LiP & $1.30 \pm 0.60$ \\
MnP & $45.83 \pm 1.81$ \\
Laccase & $21.93 \pm 0.79$ \\
Protease & $4.23 \pm 0.42$ \\
Lipase & $0.47 \pm 0.24$ \\
Amylase & $0.39 \pm 0.02$ \\
\hline
\end{tabular}


The biological treatment of leachate in column packed with Ecomat-immobilized $G$. australe mycelium was tested on $50 \%$ diluted and raw leachate. Leachate was run through the column continuously at constant flow of $20 \mathrm{ml} / \mathrm{min}$ and was recycled for 10 times. Analysis was done repeatedly after 2 cycles and the leachate parameters are shown in Table II. $\mathrm{BOD}_{5}$ content in both $50 \%$ and raw leachate was not significantly removed after each cycle except $0.14 \%$ and $1.72 \%$ removal after 4 and 10 cycles respectively, for raw leachate.

The leachate COD removal was determined by comparing the COD content for each cycle with untreated leachate (control) (Table II). For both 50\% and raw leachates, COD was significantly removed to $1645 \mathrm{mg} / \mathrm{l}$ (51.62\% removal) for diluted and $2625 \mathrm{mg} / \mathrm{l}$ (22.79\% removal) for raw leachate, repectively.

The dgradation of leachate ammoniacal nitrogen $\left(\mathrm{NH}_{3}-\mathrm{N}\right)$ by immobilized $G$. australe mycelium was also achieved in this study (Table II). The highest percentage of $\mathrm{NH}_{3}-\mathrm{N}$ removal for both leachates occurred at cycle 8 with $45.95 \%$ and $30.90 \%$ removals for diluted and raw leachates, respectively.

Treatment of leachate by immobilized $G$. australe in column showed not much change in $\mathrm{pH}$ of leachate after each cycle for both diluted and raw leachates.

TABLE II: Percentage Removal of $\mathrm{BOD}_{5}, \mathrm{COD}, \mathrm{NH}_{3} \mathrm{~N}$ AND PH CHANGES IN Diluted (50\%) AND RAW LEACHATE AFTER TREATMENT By

\begin{tabular}{|c|c|c|c|c|c|c|}
\hline \multirow[t]{2}{*}{ Cycle (C) } & \multirow[t]{2}{*}{ Parameters } & \multirow{2}{*}{$\begin{array}{c}\text { Levels in } \\
\text { Untreated } \\
\text { Leachate Control }\end{array}$} & \multicolumn{2}{|c|}{ Levels in Treated Leachate } & \multicolumn{2}{|c|}{ \% Increase / Decrease } \\
\hline & & & Raw & $50 \%$ & Raw & $50 \%$ \\
\hline \multirow[t]{4}{*}{$\mathrm{C} 2$} & $\mathrm{BOD}_{5}(\mathrm{mg} / \mathrm{l})$ & 3490.00 & 3495.00 & 3505.00 & 0.14 & 0.43 \\
\hline & $\mathrm{COD}(\mathrm{mg} / \mathrm{l})$ & 3250.00 & 3175.00 & 2705.00 & -2.36 & -16.77 \\
\hline & $\mathrm{NH}_{3}-\mathrm{N}(\mathrm{mg} / \mathrm{l})$ & 26.60 & 29.20 & 16.00 & 9.77 & -39.86 \\
\hline & $\mathrm{pH}$ & 8.05 & 8.07 & 8.01 & + & - \\
\hline \multirow[t]{4}{*}{$\mathrm{C} 4$} & $\mathrm{BOD}_{5}(\mathrm{mg} / \mathrm{l})$ & 3475.00 & 3175.00 & 3525.00 & -0.14 & 1.43 \\
\hline & $\mathrm{COD}(\mathrm{mg} / \mathrm{l})$ & 3580.00 & 3080.00 & 2530.00 & -13.97 & -29.33 \\
\hline & $\mathrm{NH}_{3}-\mathrm{N}(\mathrm{mg} / \mathrm{l})$ & 27.10 & 27.40 & 25.80 & 1.11 & -4.80 \\
\hline & $\mathrm{pH}$ & 8.05 & 8.11 & 8.06 & + & + \\
\hline \multirow[t]{4}{*}{ C6 } & $\mathrm{BOD}_{5}(\mathrm{mg} / \mathrm{l})$ & 3480.00 & 3485.00 & 3510.00 & 0.14 & 0.86 \\
\hline & $\mathrm{COD}(\mathrm{mg} / \mathrm{l})$ & 3270.00 & 3210.00 & 2050.00 & -1.83 & -37.39 \\
\hline & $\mathrm{NH}_{3}-\mathrm{N}(\mathrm{mg} / \mathrm{l})$ & 22.20 & 16.40 & 15.00 & -26.13 & -32.43 \\
\hline & $\mathrm{pH}$ & 8.05 & 8.15 & 8.08 & + & + \\
\hline \multirow[t]{4}{*}{$\mathrm{C} 8$} & $\mathrm{BOD}_{5}(\mathrm{mg} / \mathrm{l})$ & 3470.00 & 3495.00 & 3505.00 & 0.72 & 1.01 \\
\hline & $\mathrm{COD}(\mathrm{mg} / \mathrm{l})$ & 3240.00 & 3350.00 & 2080.00 & 3.40 & -35.80 \\
\hline & $\mathrm{NH}_{3}-\mathrm{N}(\mathrm{mg} / \mathrm{l})$ & 30.90 & 18.60 & 16.70 & -30.90 & -45.95 \\
\hline & $\mathrm{pH}$ & 8.05 & 8.22 & 8.13 & + & + \\
\hline \multirow[t]{4}{*}{$\mathrm{C} 10$} & $\mathrm{BOD}_{5}(\mathrm{mg} / \mathrm{l})$ & 3500.00 & 3440.00 & 3510.00 & -1.72 & 0.29 \\
\hline & $\mathrm{COD}(\mathrm{mg} / \mathrm{l})$ & 3400.00 & 2625.00 & 1645.00 & -22.79 & -51.62 \\
\hline & $\mathrm{NH}_{3}-\mathrm{N}(\mathrm{mg} / \mathrm{l})$ & $29 . .90$ & 23.60 & 23.80 & -21.07 & -21.07 \\
\hline & $\mathrm{pH}$ & 8.05 & 8.28 & 8.12 & + & + \\
\hline
\end{tabular}

- indicates reduced (removed); + indicates increased

\section{Discussion}

White-rot fungi $G$. australe was used in this study to determine the ability to remove $\mathrm{BOD}_{5}, \mathrm{COD}$, and $\mathrm{NH}_{3}-\mathrm{N}$ from leachate. This study was conducted due to the fact that biological processes play a major role in the attenuation and detoxification of organic contaminants in the environment [9].

Previous study done on pellets (free cell) and immobilized cells of Trametes versicolor showed that removal efficiency of $\mathrm{BOD}_{5}$ and $\mathrm{COD}$ in leachate was found to be higher in the case of immobilized fungi compared to free cell [17]. This is because immobilization of fungal cells could stably maintain the production of various enzymes at levels higher than achieved with pellet form. Other study by Lapadatescu et al., [18] revealed that the immobilization of Bjerkandera adusta on polyurethane foam for the production of enzymes by fungi was influenced by their cultivation method. Beshay, reported that the production of alkaline protease by $T$. turnirae was not good when cultivated in submerged cultures, since the enzyme titters were relatively low [19]. However, in a study by Lapadatescu et al., which compared two strains of $P$. chrysosporium BKM-F-1767 and INA-12 as free cells or under immobilized cell culture conditions, they found that when the fungus was immobilized, lignin and $\mathrm{Mn}$ peroxidases production were increased 2-3-fold and productivity 3-4-fold, respectively [19]. According to Omar, et al., [20] this could be attributed to the effect of shear forces and/or culture techniques on fungal morphology and fungal metabolism [21].

In this study, the treatment of leachate in column using immobilized $G$. australe mycelia on Ecomat revealed that $\mathrm{BOD}_{5}$ was not removed. This may be due to the short exposure of leachate to the immobilized mycelia at the flow-rate used. Fungal mycelia require adaptation for the enzymes to act. [17]. However, COD removal occurred at most of the cycles and diluted leachate demonstrated higher COD removal after each cycles compared to raw leachate. Similar results were found by Saetang and Babel who found 
that removal of BOD and COD was lower when the leachate was diluted 5 times compared to concentrated leachate [17].

For both concentrated and diluted leachate showed that COD removal is higher than BOD removal in most cases. This finding is in accordance with the findings by Saetang and Babel that obtained higher COD removal compared to BOD in their study [17].

The degradation of leachate ammoniacal nitrogen $\left(\mathrm{NH}_{3}-\mathrm{N}\right)$ by immobilized $G$. australe was also achieved in this study (Table II). The highest percentage of $\mathrm{NH}_{3}-\mathrm{N}$ removal for both leachate occurred at cycle 8 with $45.95 \%$ and $30.90 \%$ removals for diluted and raw leachates, respectively.

Treatment of leachate by immobilized $G$. australe in column showed not much change in $\mathrm{pH}$ of leachate after each cycle for both diluted and raw leachates. In contrast, degradation of leachate by immobilized $G$. australe in column showed that the $\mathrm{pH}$ of leachate increased from one cycle to another in both diluted and raw leachates. Rodriguez et al., [22] stated that the $\mathrm{pH}$ increase is an indicator of ammonia production.

In the column packing, immobilized mycelia of $G$. australe was applied since immobilization can eliminate most of the constraints faced by the free-cell systems such as it can facilitates operation of microbial fermentation on continuous mode without cell washout [10]. Immobilization of $G$. australe on Ecomat, a natural support offer advantages as they are compostable and inexpensive. Ecomat is a waste product of palm oil industry, whereby Ecomat could be composted once they are no longer useful as immobilization support.

Several researchers have reported success in leachate treatment using different methods previously. Secondary biological treatment from leachate of municipal solid waste landfill was done on supernatant liquid obtained after physicochemical processes and coagulating with $\mathrm{Al}^{3+}$ followed by ammoniacal stripping. The continuous experiment treatments made in an aerobic digester after physicochemical processes showed removal efficiency of COD between 69 and 83\% [23]. Aziz, et al., [24] reported that about $40 \%$ of ammoniacal nitrogen with concentration of more than $1000 \mathrm{mg} / \mathrm{l}$ could be removed by activated carbon or a mixture of carbon with limestone at mixture ratio of 5:35. Meanwhile, Ding et al., [25] reported eight effective microorganisms (EMs) could remove $25 \%$ and $40 \%$ of COD from leachate in fine sand and sabulous clay columns, respectively. A permeable biological barrier which was formed by injecting EMs into the simulated aquifer could removed $95 \%$ of leachate COD. Furthermore, Ellouze, et al., [26] demonstrated that the treatment of young landfill leachates (LFL) using selected strains of Trametes trogii, Phanerochaete chrysosporium, Lentinus tigrinus and Aspergillus niger achieved highest COD removal efficiencies for P. chrysosporium, T. trogii and L. tigrinus of 68, 79 and $90 \%$, respectively, when LFL underwent a two-fold dilution.

The potential of Ecomat-immobilized $G$. australe in leachate degradation could be related with the production of enzymes. Table I revealed that $G$. australe produced the ligninolytic enzymes (MnP, laccase and LiP) important in pollutants degradation. The ability of enzymes to degrade leachate was also supported by Zoubpulis et al., [27].

\section{CONCLUSION}

This study revealed that treatment of leachate was feasible using a white-rot fungus, Ganoderma australe mycelium immobilized on Ecomat in a column. $\mathrm{BOD}_{5}$ was not removed in diluted leachate nevertheless; in concentrated leachate, $0.43 \%$ and $1.58 \% \mathrm{BOD}_{5}$ removal occurred at cycle 4 and 10 , respectively. However, COD was removed after each cycle and diluted leachate demonstrated higher COD removal ranging from 16.77 - 51.62\% compared to raw leachate ranging from $1.83-22.79 \%$. Removal of ammoniacal nitrogen occurred for both diluted and raw leachate with the highest percentage was achieved at cycle 8 (45.95\%) for diluted leachate and $30.90 \%$ for raw leachate. Based on the results obtained, it is suggested that the percentage degradation of leachate in the column can be improved by reducing the flowrate so that it can increased the exposure time of mycelia enzymes to leachate.

\section{ACKNOWLEDGMENT}

This work is part of an on-going $\mathrm{PhD}$ thesis to be submitted to Faculty of Science, University of Malaya.

\section{REFERENCES}

[1] E. S. K. Chian and F. B. De Walle, "Sanitary landfill leachates and their treatment," J. Environ. Eng. Div., vol. 102, pp. 411-431, 1976.

[2] H. J. Ehrig, "Treatment of sanitary landfill leachate: Biological treatment," Waste Management \& Research, vol. 2, pp. 131-152, 1984.

[3] M. E. Eugenio, J. M. Carbajo, M. C. Terrón, A. E. González, and J. C. Villar, "Bioremediation of lignosulphonates by lignin-degrading basidiomycetous fungi," Bioresource Technology, vol. 99, pp. 4929-4934, 2008.

[4] S. B. Pointing, "Feasibility of bioremediation by white-rot fungi," Applied Microbiology Biotechnology, vol. 57, pp. 20-33, 2001.

[5] J. Polak and A. Jarosz-Wilkołazka, "Whole-cell fungal transformation of precursors into dyes," Microbial Cell Factories, vol. 9, pp. 51, 2010.

[6] M. Gold and M. Alic, "Molecular biology of the lignin-degrading basidiomysete Phanerochaete chrysosporium," Microbiology Review, vol. 57, pp. 605-622, 1993.

[7] Y. S. Low, N. Abdullah, and S. Vikineswary, "Biodegradation of Polycyclic aromatic hydrocarbons by immobilized Pycnoporus sanguineus on Ecomat," Journal of Applied Sciences, vol. 8, pp. 4330-4337, 2008.

[8] M. Kotterman, R. A. Wasseveld, and J. A. Field, "Hydrogen Peroxide Production as a Limiting Factor in Xenobiotic Compound Oxidation by Nitrogen-Sufficient Cultures of Bjerkandera sp. Strain BOS55 Overproducing Peroxidases," Applied and Environmental Microbiology, vol. 62, pp. 880-885, 1996.

[9] A. Mohammadi and B. Nasernejad, "Enzymatic degradation of anthracene by the white rot fungus Phanerochaete chrysosporium immobilized on sugarcane bagasse," Journal of Hazardous Materials, vol. 161, pp. 534-537, 2009.

[10] S. V. Ramakrishna and R. S. Prakasham. (2010). Microbial fermentations with immobilized cells. [Online]. Available: http://www.microbialcellfactories.com/content/9/1/51.

[11] M. Tien and T. K. Kirk, "Lignin-degrading enzyme from Phanerochaete chrysosporium: Purification, characterization, and catalytic properties of a unique H202-requiring oxygenase," in Proc. Natl. Acad. Sci. USA, vol. 81, pp. 2280-2284, 1984.

[12] J. M. Harkin and J. R. Obst., "Syringaldazine, an effective reagent for detecting laccase and peroxidase in fungi," Experientia, vol. 29, pp. 381-387, 1973.

[13] A. Leonowicz and K. Grzywnowicz, "Quantitative estimation of laccase forms in some white rot fungi using syringaldazine as a substrate," Enzyme Microb Technol, vol. 3, pp. 55-58, 1981.

[14] J. Savitha, S. Srividya, R. Jagat, P. Payal, S. Priyanki, G. W. Rashmi, K. T. Roshini, and Y. M. Shantala, "Identification of potential fungal strain(s) for the production of inducible, extracellular and alkalophilic lipase," African Journal of Biotechnology, vol. 6, pp. 564-568, 2007.

[15] J. I. Abe, F. W. Bergmann, K. Obata, and S. Hizukuri, "Production of the raw-starch digesting amylase of Aspergillus sp. K-27," Applied 
Microbiology and Biotechnology, vol. 27, pp. 447-450, 1988.

[16] APHA, Standard Methods for the Examination of Water and Wastewater, 20th ed., Washington, DC: American Public Health Association, pp. 4-75, 1998.

[17] J. Saetang and S.Babel, "Effect of le ate loading rate and incubation period on the treatment efficiency by $\mathrm{T}$. versicolor immobilized on foam cubes," International Journal of Environment Science and Technology, vol. 6, pp. 457-466, 2009.

[18] C. Lapadatescu, G. Feron, C. Vergoignan, A. Djian, A. Durand, and P. Bonnarme, "Influence of cell immobilization on the production of benzaldehyde and benzyl alcohol by the white-rot fungi Bjerkandera adusta, Ischnoderma benzoinum and Dichomitus squalens," Applied Microbiology Biotechnology, vol. 47, pp. 708-714, 1997.

[19] U. Beshay, "Production of alkaline protease by Teredinobacter turnirae cells immobilized in Ca-alginate beads," African Journal of Biotechnology, vol. 2, pp. 60-65, 2003.

[20] S. H. Omar, S. Honecker, and H.-J. Rehm, "A comparative study on the formation of citric acid and polyols and on morphological changes of three strains of free and immobilized Aspergillus niger," Applied Microbiology and Biotechnology, vol. 36, pp. 518-524, 1992.

[21] P. Bonnarme, M. Delattre, G. Corrieu, and M. Asther, "Peroxidase secretion by pellets or immobilized cells of Phanerochaete Chrysosporium BKM-F-1767 and INA-12 in relation to organelle content," Enzyme and Microbial Technology, vol. 13, pp. 727-733, 1991.

[22] B. Rodriguez, J. A. Bolbot, and I. E. Tothill, "Development of urease and glutamic dehydrogenase amperometric assay for heavy metals screening in polluted samples," Biosensors and Bioelectronics, vol. 19, pp. 1157-1167, 2004.

[23] P. Andrés, F. Gutierrez, C. Arrabal, and M. Cortijo, "Aerobic Biological Treatment of Leachates from Municipal Solid Waste Landfill," Journal of Environmental Science and Health - Part A Toxic/Hazardous Substances and Environmental Engineering, vol. 39, pp. 1319-1328, 2004.

[24] H. A. Aziz, M. N. Adlan, M. S. M. Zahari, and S. Alias, "Removal of ammoniacal nitrogen (N-NH3) from municipal solid waste leachate by using activated carbon and limestone," Waste Management \& Research, vol. 22 , pp. 371-375, 2004.

[25] A. Ding, Z. Zhang, J. Fu, and L. Cheng, "Biological control of leachate from municipal landfills," Chemosphere, vol. 44, pp. 1-8, 2001

[26] M. Ellouze, F. Aloui, and S. Sayadi, "Detoxification of Tunisian landfill leachates by selected fungi," Journal of Hazardous Materials, vol. 150, pp. 642-648, 2008.

[27] A. I. Zouboulis, M. X. Loukidou, and K. Christodoulou, "Enzymatic treatment of sanitary landfill leachate," Chemosphere, vol. 44, pp. 1103-1108, 2001.

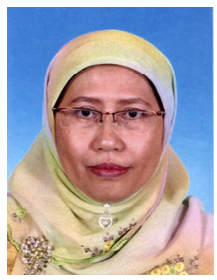

Noorlidah Abdullah had graduated in B.Sc (Medical Biochemistry) in 1984 from University of Surrey, United Kingdom, M.Sc. (Mycology) in 1989 and Ph.D (Applied Mycology) in 1997 both from University of Malaya, Malaysia.

She has contributed substantially to research, teaching and administration since she joined the Institute of Biological Sciences in 1997. Later she was promoted to associate professor in Oct 2002 and then Professor in 2008 and has become well known for her research in Fungal Biotechnology and Food Mycology. She was given due recognition for her expertise in food mycology (mycotoxins) by the Ministry of Health for whom she has been an expert committee in Asean Expert Group On Food Safety and Food Additives and Contaminants Committee. She has published 70 articles in reputable journals and book chapters and has supervised 48 postgraduate students.

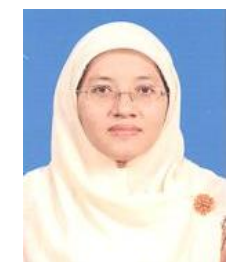

Wan Razarinah Wan Abdul Razak was born in Kuantan, Pahang, Malaysia on February 24, 1970. She obtained her B.Sc. of Applied Sciences (Hons.) in Biotechnology in 1994 and M.Sc. in Biology in 1999 both from Universiti Sains Malaysia.

She had worked as a microbiologist at Biochem Laboratories Sdn. Bhd. from 1977 to 2003 and as Lecturer at Faculty of Applied Sciences, Universiti Teknologi MARA from 2003 until to date.

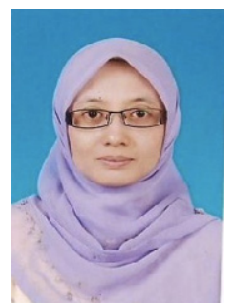

Noor Zalina Mahmood was born in Johore on $4^{\text {th }}$ January 1969. The author obtained her first degree in Ecology in 1993 from University of Malaya, Malaysia and completed her PhD in 2000 from University of Strathclyde, United Kingdom in Solid Waste Management.

She is cuurently a senior lecturer of Institute of Biological Sciences, Faculty of Science, University of Malaya, Malaysia. She has

involved with numerous research related to solid waste management and published journals.

Dr. Noor Zalina is also a member of Japan Society for the Promotion of Science (JSPS)-Asian Core Program: Research and Education Center for the Risk Based Asian Oriented Integrated Watershed Management. She currently works on treatment and utilisng waste such as agriculture waste, municipal and cosntruction waste.

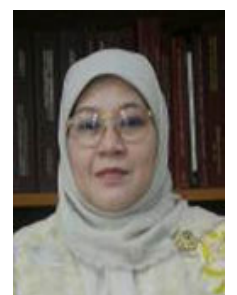

Rosna Mat Taha was born in Malaysia on January 22, 1958. In 1984, she obtained her B.Sc. in Botany from University of Malaya, Kuala Lumpur, Malaysia and eventually completed her Ph.D in 1989 on Plant Morphogenesis from University of Wales, Cardiff, UK.

She is currently working as a lecturer (professor) at Institute of Biological Sciences, Faculty of Science, University of Malaya, Kuala Lumpur, Malaysia. She has published more than 100 papers in ISI-cited journals, proceedings, book chapters and etc.

Prof. Taha is also an expert in plant tissue culture, morphogenesis, biotechnology, pigment and cellular behavior studies. She has won many awards (more than 20) in her research. She is a member of European Association for Research on Plant Breeding (EUCARPIA) and International Society for Horticultural Science (ISHS). Also, she is the associate editor of Asian Journal of Biotechnology, Asian Journal of Plant Sciences and Journal of Applied Sciences. 